\title{
SORPTION OF APOLAR PESTICIDES BY UNITS OF BENZOIC ACID PROPYL ESTER IN CYCLIC PHOSPHAZENE
}

\author{
JORGE RIVAS*1,2, MARÍA LUISA VALENZUELA*I \\ ${ }^{I}$ Institute of Applied Chemical Sciences, Inorganic Chemistry and Molecular Materials Group, Universidad Autónoma de Chile \\ El Llano Subercaseaux 2801, San Miguel, Santiago, Chile. \\ ${ }^{2}$ Department of Chemistry, Faculty of Applied Sciences, Universidad Andres Bello, Republica 257, Santiago, Chile.
}

\begin{abstract}
The effects of temperature, $\mathrm{pH}$ and agitation time (equilibrium) on the adsorption process of different pesticides on $\mathrm{N}_{3} \mathrm{P}_{3}\left(\mathrm{OC}_{6} \mathrm{H}_{4} \mathrm{COOCH}_{2} \mathrm{CH}_{2} \mathrm{CH}_{3}\right)_{6} \mathrm{Was}$ studied. With optimal conditions experimental, the adsorption isotherms have been realized with through Langmuir and Freundlich models. Pesticides are compounds used mainly in agriculture to control various species (plants, insects, worms, fungi). Due to their physicochemical properties, they can remain for a long time in the application sites, bioaccumulating and moving between environmental compartments which generate various environmental problems. The results obtained showed a physisorption mechanism for the five pesticides studied, with higher sorption for: azinphos methyl (93,5 mg kg-1), carbaryl (290.5 mg kg-1) and carbofuran $\left(580.5 \mathrm{mg} \mathrm{kg}^{-1}\right)$ at $20^{\circ} \mathrm{C}$, according to the models used.
\end{abstract}

Keywords: Sorption, pesticides, cyclic phosphazene.

\section{INTRODUCTION}

Pesticides are agrochemicals that have been used to improve the conditions of different crops, eliminating various species that have negative effects on plantations ${ }^{1,2}$. There are a large number of pesticides, mainly because they have negative effects on human health, and many of them have been banned ${ }^{3-6}$. Pesticides have a distribution and different patterns of persistence on environment, by physical and chemical properties. For this reason, pesticides have been found in air, water, soils, sediments, rivers and lakes, and living tissues ${ }^{7-12}$; their concentration depend of matrix properties ${ }^{13,14}$, and weather conditions ${ }^{15,16}$. The environment entry of pesticides occurs by the application in crop fields to remove animal or plant pests where their effects are almost immediate ${ }^{19}$ considering studies conducted in animals and people ${ }^{17,18,19}$.

Taking into account the large number of pesticides that exist (ionic and non-ionic pesticides, organochlorines (OCP), organophosphates (OPP), pyrethroids (PP), etc.), with various chemical properties, the development of new methodologies to determine the The content of these analytes in different matrices is necessary, and in this way they are a viable alternative to existing techniques ${ }^{20-24}$.

The solid extraction liquid systems (SLE) are based on solid sorbents, i.e solid phase micro-extraction (SPME), stir bar stirring extraction (SBSE), membrane-assisted solvent extraction (MASE), liquid phase micro-extraction (LPME), dispersive liquid-liquid dispersive micro-extraction (DLLME)) which interact with the analytes and can be separated from the matrix, retaining them, and / or using solvents of a different nature to preconcentrate and then determine them by techniques, including by gas or liquid chromatographies ${ }^{25-29}$.

Taking as a base sorbents that deal with SPME or SBSE, some alternative solid sorbent have been used or synthesized to improve these techniques. For example, nanoparticles and zeolites modified ${ }^{29}$, graphene modified ${ }^{30}$ and organic matter modified ${ }^{31}$.

In this study, cyclophosphazenes and their derivatives are proposed as a new alternative. They have a cyclic arrangement between nitrogen and phosphorous atoms with alternating single and double bonds. Cyclophosphazenes respond to a general formula $[N P R]_{n}(n=3$ or 4$)$, where $n$ represents the number of units $(\mathrm{n}=3$, cyclotriphosphazene). If, $\mathrm{n}$ is greater, cyclophosphazene can be ordered as oligomers to polymers. From hexachlorocyclotriphosphazene, a variety of substituted cyclophosphazene have been synthesized by replacing the chlorine atoms with different functional group through a nucleophilic substitution reaction $^{32,33}$.

Several substitutions can be made over the phosphorus atom, so these substituted cyclic trimers have seen applied in catalytic studies ${ }^{33}$ several reactions $^{34-37}$, fuel cell applications ${ }^{38}$, flame retardant studies ${ }^{39}$, but the literature does not show any sorption study on these types of phosphazene with pesticides. Comparatively, a number of studies have been carried out on other sorbents such as siloxanes modified ${ }^{40,41}$, silica $^{42}$, zeolites ${ }^{43,44}$, activated carbon $^{45,46}$, and other sorbents ${ }^{47,48}$ showing positive results with pesticides. In this way, this work represents a first advance in knowing the potential sorption properties of cyclic phosphazenes substituted with pesticides, since, there are no studies on the sorbent properties that may have phosphazenes modified with organic compounds (polycyclic aromatic hydrocarbons (PAHs), polychlorines byphenyls (PCBs), polybrominated diphenyl ethers (PBDEs), pesticides), but the literature shows adsorption studies on modified phosphazene (trimers o polymers) units in compounds such as methylene blue $e^{49,50}$, amines ${ }^{51}$, proteins ${ }^{52}$. In this work is proposed that an unit prepared of benzoic acid propyl ester in cyclic phosphazene would sorb some pesticides, determining the optimum conditions for the adsorption process, and correlating the adsorption properties of the analytes with some appropriate adsorption models

\section{EXPERIMENTAL SECTION}

Chemicals. $1000 \mu \mathrm{g} \mathrm{mL} \mathrm{m}^{-1}$ of pesticide standard mixture solution was prepared in acetonitrile (Lichrosolv grade, Merck Germany). The pesticides selected (azinphos-methyl, carbaryl, carbofuran, chlorpyriphos, and chlorothalonil) were obtained from Sigma \& Aldrich (St. Louis, MO, USA). This solution was then used for calibration and pesticides sorption studies. To synthesize cyclic phosphazene unit, it was utilized phosphonitrilic chloride trimer (Sigma-Aldrich), sodium propyl 4-hydroxybenzoate 99\% (Sigma-Aldrich), acetone (Lichrosolv grade, Merck), benzene (analytical grade, Merck), y Nitrogen ultrapure (Linde, Santiago, Chile). To monitorize and to characterize the phosphazene obtained were used deuterium oxide (water- $\mathrm{d}_{2}$ ) and chloroform- $\mathrm{d}_{1}$ (Sigma-Aldrich). For sorption studies and optimization of experimental conditions ( $\mathrm{pH}$, temperature, stirring time) were utilized $\mathrm{CaCl}_{2}, \mathrm{NaOH}, \mathrm{HCl}$, (analytical grade, Merck), acetonitrile (Lichrosolv grade, Merck) and deionized water (NANOpure ultrapure water system; Barnstead, Dubuque, IA, USA). Deionized water was used for the preparation of all aqueous solutions.

Equipment and chromatographic procedure. Determination of pesticides selected was carried out by HPLC (Jasco, Japan) with quaternary pump model PU-2089s, and diode array detector model MD-2010, using an Inersil ${ }^{\circledR}$ ODS-3 (GLSciencies, Tokio, Japan) RP-C18 column ( 250 x $4.6 \mathrm{~mm}$ i.d., $5 \mu \mathrm{m}$ particle size). A $20 \mu \mathrm{L}$ sample was injected into the column. Mobile phase was an acetonitrile $(\mathrm{ACN})$ /deionized water in gradient. The gradient program was ACN:water 60:40, at $0-2 \mathrm{~min}, \mathrm{ACN}$ :water 70:30, at $2-5 \mathrm{~min}, \mathrm{ACN}$ :water 80:20, at $7-12 \mathrm{~min}, \mathrm{ACN}$ :water 100:0, at $12-15 \mathrm{~min}$. Total time $15 \mathrm{~min}$ and flow $1,5 \mathrm{~mL} \mathrm{~min}^{-1}$.

Preparation of $\mathrm{N}_{3} \mathrm{P}_{3}\left(\mathrm{OC}_{6} \mathrm{H}_{4} \mathrm{COOCH}_{2} \mathrm{CH}_{2} \mathrm{CH}_{3}\right)_{6}$. The synthesis was performed following the route previously described by Miyata et al. ${ }^{53}$. A solution of phosphonitrilic chloride trimer (hexachlorocyclotriphosphazene) (20 g; $0,058 \mathrm{~mol})$ in dry benzene and sodium propyl 4-hydroxybenzoate $(66,9 \mathrm{~g} ; 0,4$ mol) was stirred at room temperature in nitrogen atmosphere for $24 \mathrm{~h}$. The 
resulting mix was filtered off and the solvent was removed under reduced pressure. The precipitated white solid was collected to structural characterization.

The characterization was performed using nuclear magnetic resonance spectrometer $\left({ }^{1} \mathrm{H}-\mathrm{NMR},{ }^{31} \mathrm{P}-\mathrm{NMR}(400 \mathrm{MHz})\right.$, Bruker 400 ultrashield avance, Bruker, Germany). Solid IR spectra were recorded on $\mathrm{KBr}$ dishes in the 400 $4000 \mathrm{~cm}^{-1}$ range, Solid IR spectra were obtained with infrared spectrometer (WQF-510 FTIR, Beijing Rayleigh Analytical Corp, China). The characteristics for the phosphazene synthesized were: yield $87 \%, \mathrm{mp} 91^{\circ} \mathrm{C}$. IR $(\mathrm{KBr}) 1730$ $1580,1500,1440,1200,1150 \mathrm{~cm}^{-1} .{ }^{1} \mathrm{H} \mathrm{NMR}\left(\mathrm{CDCl}_{3}\right.$, TMS) $\delta 6,8-7.9(\mathrm{~m}$ $24 \mathrm{H}$, arom $\mathrm{H}), 4.2\left(\mathrm{t}, 12 \mathrm{H},-\mathrm{CH}_{2}-\right), 1.7\left(\mathrm{~m}, 12 \mathrm{H},-\mathrm{CH}_{2}-\right), 1.3\left(\mathrm{t}, 18 \mathrm{H},-\mathrm{CH}_{3}\right)$. ${ }^{31} \mathrm{P}$ NMR $\left(\mathrm{D}_{2} \mathrm{O}, \mathrm{CDCl}_{3}\right) \delta 8,0$.

Experimental conditions optimization. Aliquots (approximately $30 \mathrm{mg}$ ) of sorbent synthesized were accurately weighed in triplicate and suspended in $3 \mathrm{~mL}$ of a mixture $(1: 1, \mathrm{v} / \mathrm{v})$ of acetonitrile and $\mathrm{CaCl}_{2} 0.01 \mathrm{~mol} \mathrm{~L}^{-1}$. The resultant mixtures were spiked with pesticides mixture solution to reach final concentrations from $5 \mu \mathrm{g} \mathrm{mL} \mathrm{m}^{-1}$ and stirred for $24 \mathrm{~h}$. To study temperature effect each solution was stirred $(200 \mathrm{rpm})$ at three different temperatures $(10,20$ and $\left.30^{\circ} \mathrm{C}\right)$. The $\mathrm{pH}$ effect was studied under the same conditions; it was selected four $\mathrm{pH}$ values $(0,4,7,10)$. To vary $\mathrm{pH}, \mathrm{CaCl}_{2}$ was prepared previously with $\mathrm{HCl}$ or $\mathrm{NaOH}$ to obtain adequate $\mathrm{pH}$ in each experiment. Finally, each solution was filtrated at $0.22 \mu \mathrm{m}$, and analyzed by liquid chromatography.

Studies of sorption. The sorption studies (adsorption isotherms) were made with aliquots (approximately $30 \mathrm{mg}$ ) of sorbent were accurately weighed in triplicate and suspended in $3 \mathrm{~mL}$ of a mixture $(1: 1, \mathrm{v}: \mathrm{v})$ of acetonitrile and $\mathrm{CaCl}_{2} 0.01 \mathrm{~mol} \mathrm{~L}^{-1}$ at $\mathrm{pH}$ 7. The resultant mixtures were spiked with pesticides mixture solution to reach final concentrations from 0.1 to $20 \mu \mathrm{g} \mathrm{mL}^{-1}$ and stirred $(200 \mathrm{rpm})$ for $24 \mathrm{~h}$ at $20^{\circ} \mathrm{C}$. Finally, each solution was filtrated at 0.22 $\mu \mathrm{m}$, and analyzed by liquid chromatography.

\section{RESULTS AND DISCUSSION}

Effect of stirring time and $\mathbf{p H}$. The determination of the sorption capacity of sorbent synthesized requires the knowing of other parameters. One of them represents the time of agitation (equilibrium time). It is important to establish the time at which the pesticide solution system and the solid reach the equilibrium state to determine the maximum capacity of sorption under this condition ${ }^{54}$. The equilibrium time was investigated over a range of 1 and $72 \mathrm{~h}$, under stirring. All the pesticides studied reached equilibrium after $20 \mathrm{~h}$ Therefore, a time of $24 \mathrm{~h}$ was selected to the next experiments. Under the study of this variable, the differences in the retained amounts of each pesticide are related by the interaction of these with the solid sorbent (Figure 1).

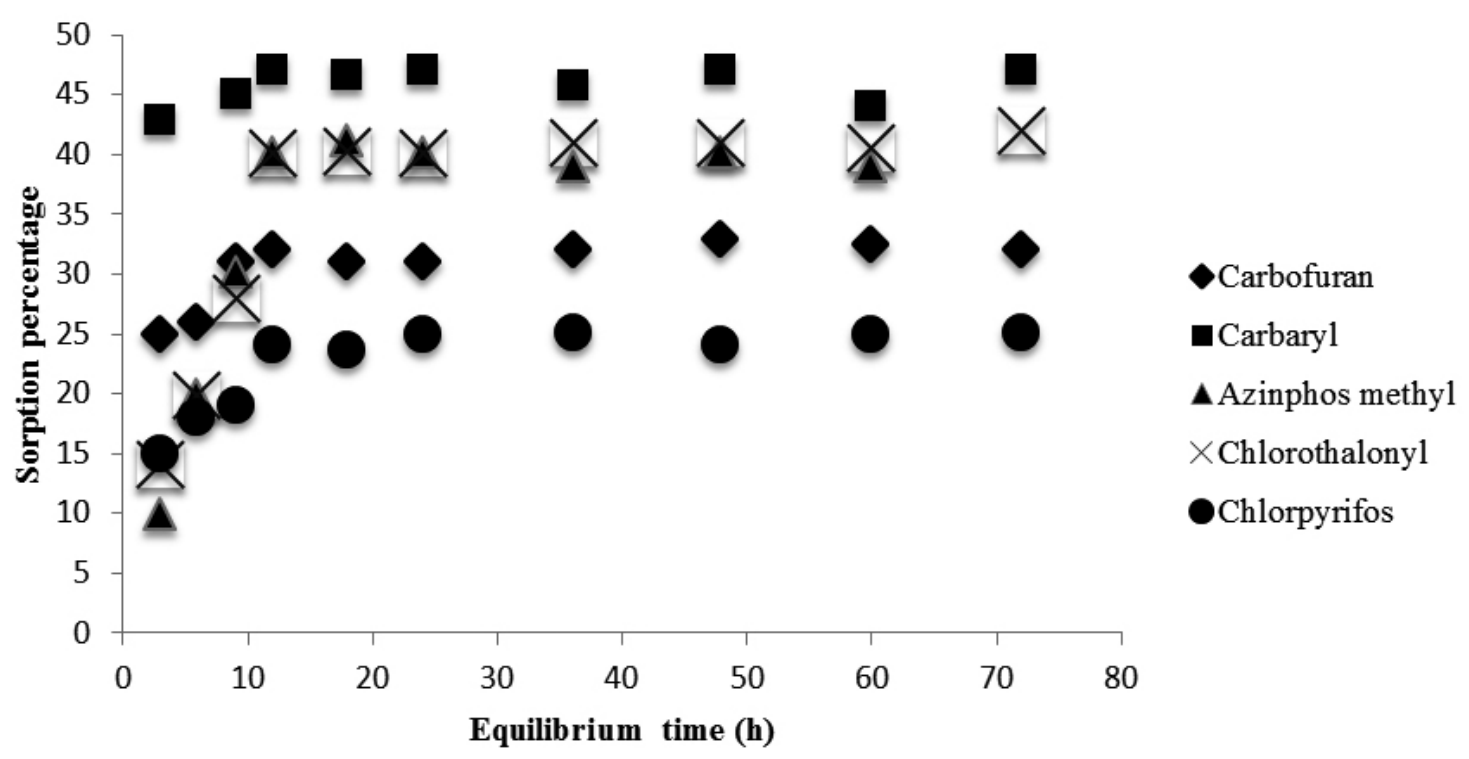

Figure 1. Effect of stirring time on equilibrium process to sorption of pesticides in the sorbent synthesized. (The $\mathrm{X}$ axis represents the stirring time of each batch solution and the $\mathrm{Y}$ axis represents the amount retained on solid). Concentration each pesticide: $5 \mu \mathrm{g}$ $\mathrm{mL}^{-1}$, final volume: $3 \mathrm{~mL}$, time range: $1-6-12-24-36-48-60-72 \mathrm{~h}$

Due to the low solubility of pesticides in water, the use of pure water or aqueous solutions was not feasible to studying sorption thus this effect is indistinguishable from precipitation.

Consequently, a solvent mixture containing acetonitrile and calcium chloride $0.01 \mathrm{~mol} \mathrm{~L}^{-1}$ in a 60:40 ratio was selected to keep the pesticides dissolved after equilibrium and to maintain the ionic strength ${ }^{55}$. Despite the percentage of acetonitrile is impractical; the constructed isotherm was useful for estimating the amount of pesticides adsorbed by the matrix. Initially only acetonitrile was considered as solvent in the studies.

The $\mathrm{pH}$ effect plays a fundamental role in the sorption process ${ }^{56}$. The $\mathrm{pH}$ may modify the surface of the sorbent, and alter the ionic equilibrium of the analytes, and other components of the solution. In this case, the influence of $\mathrm{pH}$ on ionic equilibrium is for carbaryl (acidic group, $\mathrm{pKa}=3.68$ ) and carbofuran (basic group, $\mathrm{pKa}=10.4$ )

If the $\mathrm{pH}$ of the solution is acid the nonionic form of carbofuran and carbaryl predominates. Thus, both analytes will be more retained on a no-charged surface, though, e.g., dipole-dipole interactions. For the rest of the analytes, $\mathrm{pH}$ does not affect its structure. Higher retention will be obtained on a sorbent with a surface without electric charges.

The effect of $\mathrm{pH}$ was investigated over a range of 0-10 (Figure 2). The $\mathrm{pH}$ range was considered under the most extreme experimental conditions. The $\mathrm{pH}$ did not have a considerable effect on the surface of sorbent used $\left(\mathrm{N}_{3} \mathrm{P}_{3}\left(\mathrm{OC}_{6} \mathrm{H}_{4} \mathrm{COOCH}_{2} \mathrm{CH}_{2} \mathrm{CH}_{3}\right)_{6}\right)$ because does not have ionizable groups but the $\mathrm{pH}$ affect carbaryl and carbofuran (ionizable and no ionizable forms). When the $\mathrm{pH}$ increased, the carbaryl ionized so that on the more apolar surface of the $\mathrm{N}_{3} \mathrm{P}_{3}\left(\mathrm{OC}_{6} \mathrm{H}_{4} \mathrm{COOCH}_{2} \mathrm{CH}_{2} \mathrm{CH}_{3}\right)$, the amount retained is less. Otherwise, carbofuran was retained in most of the range, but at $\mathrm{pH} 10$ its value decreased. As calcium ion precipitates at $\mathrm{pH}$ greater than 10 (as calcium hydroxide), it was not investigated at higher $\mathrm{pH}$. Since the surface of sorbent is not affected by $\mathrm{pH}$, and having a more apolar surface, therefore the most apolar analytes (azinphos methyl, chlorothalonil, chlorpyrifos) (less solubility in water) were not more retained on the surface. As shown in Figure 2, the sorption of carbofuran and carbaryl decreases as the $\mathrm{pH}$ increases, whereas for the other pesticides the sorption is similar. In these cases, hydrophobic interactions (i. e. dipole-dipole interactions, Van der Waals forces, $\pi-\pi$ stacking interactions) may be expected to predominate in these cases when considering the structures 
of the compounds and the sorbent used.

Considering studies on real crop water matrices, whose $\mathrm{pH}$ is close to 7 , this value was selected for the study of subsequent adsorption isotherms.

Adsorption isotherms. Adsorption isotherms was to determine the maximum load of pesticides that can be bound to the matrix without saturating the active sites.

An adsorption isotherm is a relationship between the amount of an analyte that is adsorbed from solution and held until reaching a steady state at a constant temperature and pressure. Adsorption isotherms for pesticides were studied in a batch system containing a fixed amount of sorbent at three different temperatures $\left(10-20\right.$ and $\left.30^{\circ} \mathrm{C}\right)$, and the results are shown in Figure 3.

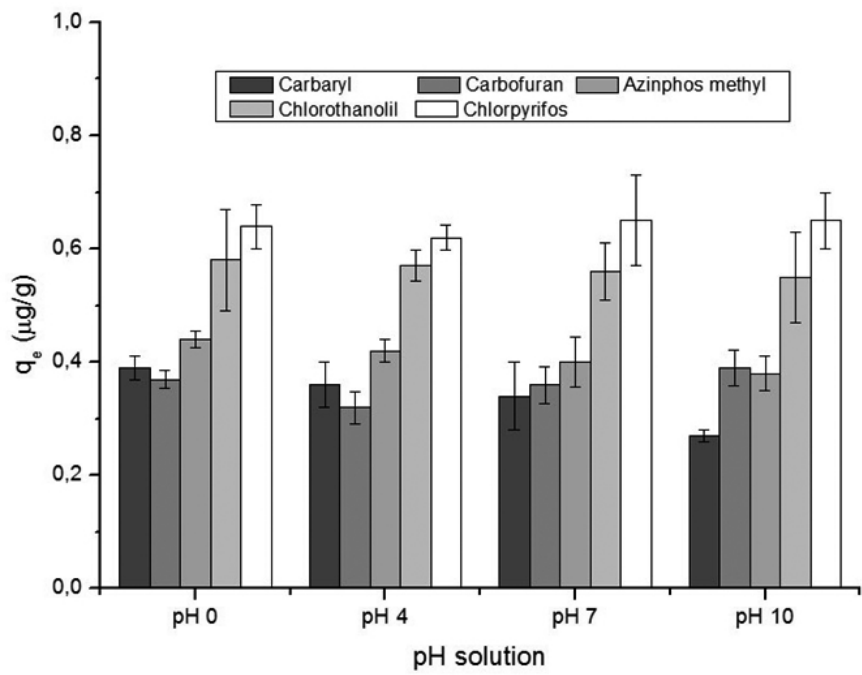

Figure 2. Effect of $\mathrm{pH}$ on sorption of pesticides (The $\mathrm{X}$ axis represents the $\mathrm{pH}$ of each batch solution and the $\mathrm{Y}$ axis represents the amount retained on sorbent). Sorbent: $30 \mathrm{mg}$, final volume: $3 \mathrm{~mL}$, stirring time $24 \mathrm{~h}$. Concentration each pesticide: $5 \mu \mathrm{g} \mathrm{mL} \mathrm{m}^{-1}$

Sorption is a process of accumulating an analyte on and at the interface between a solid and liquid phase, in which there is no defined mechanism. The absorption process involves a three-dimensional arrangement and change in the structure of the analytes; in contrast, the adsorption is through a twodimensional process, with weaker interactions and without change in the structure of the analytes ${ }^{23}$

As shown in Figure 3, for carbofuran, carbaryl has type I isotherm behavior, which means that when the concentration increases the active sites are occupied until the saturation of these. In this case, the sorbates cover the surface of the sorbent forming a monolayer and the adsorption process stops ${ }^{57}$. By the nature of the analytes and their affinity with the sorbent, the nonpolar analytes (chlorothalonil, chlorpyrifos and azinphos-methyl) obtained a relatively linear relation, which means that no matter the concentration of these analytes, the sorbent will be able to retain these analytes in low and high concentrations (type $\mathrm{C}$ isotherm) ${ }^{58}$

These results show that the sorbent used has the capacity to retain the pesticides studied, but in the case of carbofuran and carbaryl (fig 3 (a, b)) saturation level of the active sites can be reached, considering the chemical properties of the sorbent. In the case of the other three pesticides chlorothalonil, chlropyrifos and azinphos methyl (fig 3 (c, d and e), saturation is not reached, resulting in a linear equilibrium between the solid phase and solubility in the liquid phase, so that the amount of analyte can be increased without the active sites being completely occupied. This behavior occurs in those compounds which may have a low polarity ${ }^{53}$, since their concentrations in a liquid phase may be low (e.g., by precipitation).

Considering the nature of these three pesticides, the concentration levels in which they it can be found in actual samples of water and soils, a higher concentration range and a different behavior were not studied (equilibrium of the analytes between the phases, formation of multilayers, new levels of saturation).

By the chemical structure of sorbent used, due to the functional groups that it possesses, the most retained analytes are the most apolar, and therefore, the effect of modification of charge by the change of $\mathrm{pH}$ does not alter the surface and had no effect on the analytes, except carbaryl and carbofuran (Figure 2). This opens the possibility of generating a new sorbent compound with other functional groups to study the retention capacity of these pesticides and others.

To determine the sorption retention capacity of sorbent used, under studied conditions, some models for isotherms were used. Different models, such as Langmuir, Freundlich, Brunauer, Emmet, Teller (BET) ${ }^{25}$, distributed reactivity $(\mathrm{DRM})^{25}$, dual-mode $(\mathrm{DMM})^{26}$, have been used to describe the sorption of organic pollutants, mathematically. Table 1 and 2 show the parameters calculated with the classic models (Langmuir and Freundlich models).

For the Freundlich model, when the temperature increased from 10 to 30 ${ }^{\circ} \mathrm{C}$, the value of $\mathrm{n}$ was closer to 1 , for apolar pesticides, obtaining a linear sorption behavior (Figure 3), for apolar pesticides, a linear soption behavior was obtained when the temperature increases from 10 to $30^{\circ} \mathrm{C}$ considering Freundlich model. the values of Freundlich constant $\left(\mathrm{K}_{\mathrm{F}}\right)$ were higher for azinphos methyl, chlorothalonil and chlropyrifos (more retained), which were also higher at higher temperatures. Using the Langmuir model ${ }^{25,59}$, it was determined that the highest retention was observed in the most nonpolar pesticides, a result that is related to the other model. Azinphos methyl, chlorothalonil and chlropyrifos are the most retained pesticides (higher values of $\mathrm{Q}_{0}$ ) and with small values, so the adsorption energies of pesticides on sorbent would be low (not shown).

Table 1 Sorption parameters of the Freundlich and Langmuir isotherm models describing pesticides adsorption, at $20^{\circ} \mathrm{C}$.

\begin{tabular}{|l|c|c|c|c|c|c|}
\hline & \multicolumn{2}{|c|}{ Parameters of Freundlich model } & \multicolumn{3}{c|}{ Parameters of Langmuir model } \\
\hline Pesticide & $\mathrm{K}_{\mathrm{F}}$ & $\mathrm{n}$ & $\mathrm{r}^{2}$ & $\mathrm{Q}_{\mathrm{o}}$ & $\mathrm{b}$ & $\mathrm{r}^{2}$ \\
\hline Carbofuran & $219,8 \pm 9,9$ & $0,28 \pm 0,08$ & 0,976 & $612,7 \pm 37,7$ & $0,13 \pm 0,001$ & 0,876 \\
\hline Carbaryl & $29,8 \pm 2,6$ & $0,43 \pm 0,09$ & 0,945 & $308,9 \pm 45,5$ & $0,028 \pm 0,07$ & 0,789 \\
\hline Azinphos-methyl & $14,8 \pm 1,1$ & $0,76 \pm 0,12$ & 0,987 & $218,1 \pm 15,4$ & $0,013 \pm 0,0099$ & 0,788 \\
\hline Chlorothalonyl & $2,8 \pm 0,5$ & $0,99 \pm 0,21$ & 0,997 & $214,0 \pm 9,9$ & $0,0122 \pm 0,0035$ & 0,910 \\
\hline Chlorpyrifos & $1,8 \pm 0,1$ & $0,99 \pm 0,10$ & 0,923 & $77,3 \pm 5,6$ & $0,00922 \pm 0,0013$ & 0,934 \\
\hline
\end{tabular}



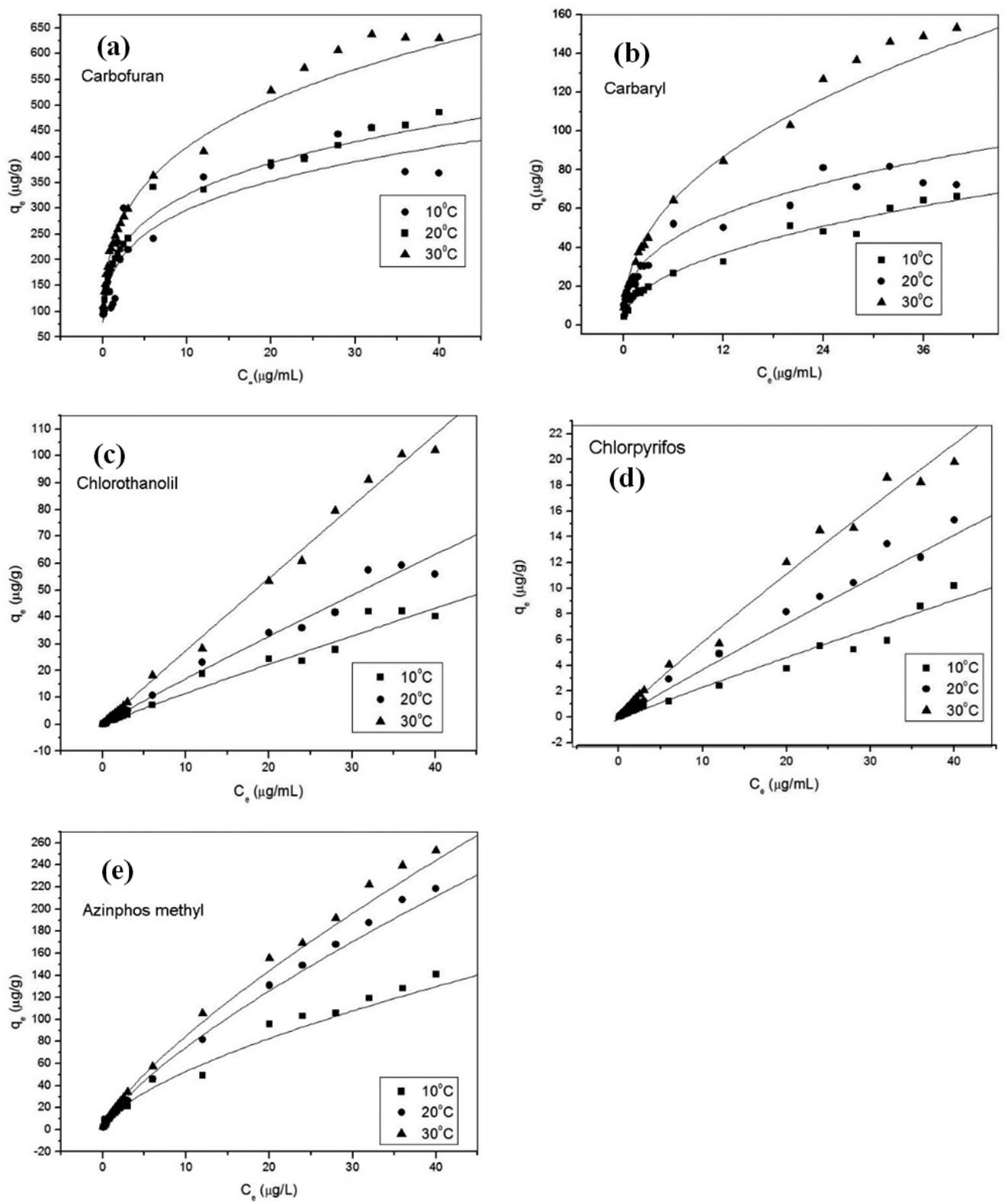

Figure 3. Adsorption isotherms for each pesticide on $\mathrm{N}_{3} \mathrm{P}_{3}\left(\mathrm{OC}_{6} \mathrm{H}_{4} \mathrm{COOCH}_{2} \mathrm{CH}_{2} \mathrm{CH}_{3}\right)_{6}$ at different temperatures Carbofuran (a), Carbanyl (b), Chlorothalonil (c), Chlopyrifos (d), Azinphos-methyl (e). (The X axis represents the amount in equilibrium of each batch solution and the Yaxis represents the amount retained on sorbent used).

As shown in the isotherms (Figure 3), the carbofuran y carbaryl exhibited a non-linear relationship, which was also established in the values of $1 / \mathrm{n}$ (all lower than 1) calculated from the Freundlich mode ${ }^{25,59}$. To compare the effectiveness and validity of the model, some statistical parameters were analyzed. The coefficient of determination $\left(\mathrm{r}^{2}\right)$ showed that both models are useful to explain the sorption of analytes, butthe higher values of $\mathrm{r}^{2}$ were by the Freundlich model (Table 1), therefore, this model is appropriate to describe the sorption of pesticides in the samples studied.

Since this model gives a constant, which is related to the equilibrium that the analyte reaches between the solid and liquid phases can be calculated thermodynamic values for the process of sorption, by the ratio of the free energy of Gibbs and the equilibrium constant of the system. Table 2 show the calculated results at $30^{\circ} \mathrm{C}^{59}$.
Table 2. Thermodynamic parameters for the sorption of studied pesticides.

\begin{tabular}{|l|c|c|c|}
\hline & $\Delta \mathrm{H}\left(\mathrm{kJ} \mathrm{mol}^{-1}\right)$ & $\Delta \mathrm{S}\left(\mathrm{J} \mathrm{mol}^{-1} \mathrm{~K}^{-1}\right)$ & $\Delta \mathrm{G}_{303}\left(\mathrm{~kJ} \mathrm{~mol}^{-1}\right)$ \\
\hline Carbofuran & $-14,86$ & 9,98 & $-17,88$ \\
\hline Carbaryl & $-14,03$ & 10,81 & $-17,31$ \\
\hline Azinphos-methyl & $-10,81$ & 9,15 & $-13,60$ \\
\hline Chlorothalonil & $-11,91$ & 6,90 & $-14,00$ \\
\hline Chlorpyrifos & $-11,18$ & 6,24 & $-13,07$ \\
\hline
\end{tabular}

Because organic compounds may interact with the solid matrix through different mechanisms, these models can assist with the interpretation of the sorption. To understand the probable sorption mechanism of the pesticides on 
the sorbent used, different thermodynamic parameters were calculated. The calculated values are shown in Table 2, indicating that the sorption process was spontaneous, and exothermic. The calculated Gibbs free energy values were between -14 and $-17 \mathrm{~kJ} \mathrm{~mol}^{-1}$, suggesting that the sorption mechanism of pesticides on sorbent selected was through physisorption. Therefore, the Freundlich model should be satisfactory for describing the behavior of the analytes. This mechanism would allow a less laborious desorption, considering the extraction systems in the following studies.

\section{CONCLUSIONS}

The phosphazene $\mathrm{N}_{3} \mathrm{P}_{3}\left(\mathrm{OC}_{6} \mathrm{H}_{4} \mathrm{COOCH}_{2} \mathrm{CH}_{2} \mathrm{CH}_{3}\right)_{6}$ studied has sorbent properties, especially in less polar analytes (azinphos methyl, chlorothanolyl, chlorpyrifos), so it is expected that analytes with low polarity can be retained, especially in those where the effects of change in surface charge does not it affects them. In this case, the study conditions were carried out at $\mathrm{pH} 7,30^{\circ} \mathrm{C}$ and an equilibrium time of $24 \mathrm{~h}$.

According to the thermodynamic values calculated from the data of the Langmuir and Freundlich models, carbofuran and carbaryl were the least retained pesticides. The sorption processes of the pesticides studied were exothermic and spontaneous, through a mechanism of physisorption, which would allow an easier desorption. The calculated values hold that the most commonly absorbed pesticides are the compoundswith the least polarity, where the process is most likely thermodynamically, when the temperature is higher.

The pesticides studied have different uses, therefore this work presents an approximation to the behavior they can present on the selected sorbent and allows to establish the initial conditions to carry out individual or group studies of these pesticides and others in real samples. In later studies, we will study the effect of other pesticides polar and sorption differences on other cyclic phosphazenes with other substituents.

\section{ACKNOWLEDGEMENTS}

The authors thank FONDECYT (Project 3140407) for financial support.

1.- A. Mkindi, N. Mpumi, Y. Tembo, P.C. Stevenson, P.A. Ndakidemi, K. Mtei, R. Machunda, S.R. Belmain Ind. Crop. Prod., article in press (2017)

2.- C. Zhang, S. Guanming, J. Shen, R-f. Hu R-f J. Integr Agr. 14(9) 1903 (2015)

3.- U. Hass, S. Christiansen, M. Axelstad, M. Scholze, J. Boberg Reprod. Toxicol. 72, 97 (2017)

4.- N.I. Rousis, E. Zuccato, S. Castiglioni Environ. Int. 99, 213 (2017

5.- V. Yusa, M. Millet, C. Coscolla, M. Roca Anal. Chim. Acta 3, 15 (2015)

6.- M.F.A. Jallow, D.G. Awadh, M.S. Albaho, V.Y. Devi, B.M. Thomas Environ. Int. 107, 100 (2017

7.- E. Silva, M.A. Daam, M.J. Cerejeira Chemosphere 135, 394 (2015)

8.- J.P. Pascual Aguilar, V. Andreu, J. Campo, Y. Picó, A. Masiá Sci. Total Environ. 607-608, 752 (2017)

9.- J.L. Sánchez-Osorio, J.V. Macías-Zamora, N. Ramírez-Álvarez, T.F. Bidleman Chemosphere, 173, 275 (2017)

10.- LA. Suddaby, S. Beulke, W. van Beinum, R.G. Oliver, S. Kuet, C.D. Brown Chemosphere 162, 40 (2016)

11.- Z. Zhao, Y. Jiang, Q. Li, Y. Cai, H. Yin, L. Zhang, J. Zhang Ecotoxicol. Environ. Safe. 142, 117 (2017)

12.- V.D. Dang, K.J. Kroll, S.D. Supowit, R.U. Halden, N.D. Denslow Environ. Poll. 216, 877 (2016)

13.- K. Demeestere, J. Dewulf, B. De Witte, H. Van Langenhove J. Chromatogr. A, 1153, 130 (2007)

14.- G. Bapat, C. Labade, A. Chaudhari, S. Zinjarde Chemosphere 166, 21 (2017)

15.- P. Janoš, M. Kormunda, F. Novák, O. Životský, J. Fuitová, V. Pilařová Reac. Func. Pol. 73, 46 (2013)

16.- L.M. Jantunen, P.A. Helm, J.J Ridal, T.F. Bidleman Atmos. Environ. 36, 8533 (2008)

17.- N.I. Rousis, R. Bade, L. Biilsma, E. Zuccato, J.V. Sancho, F. Hernandez, S. Casrtiglioni Environ. Res. 156, 31 (2017)

18.- A. Thomas, L. Toms, F.A. Harden, P. Hobson, N. White, K. Mengersen, J. Mueller Environ. Res., 154, 10 (2017)

19.- A. Achour, A. Derouiche, B. Barhoumi, B. Kort, D. Cherif, S. Bouabdallah, M. Sakly, K.B. Rhouma, S. Touil, M.R. Driss, O. Tebourbi Environ. Res. 156, 635 (2017)
20.- D. Baglio, D. Kotzias, B. Richter Larsen J. Chromatog. A 854 (1-2), 207 (1999)

21.- Z. Cheng, F. Dong, J. Xu, Z. Liu, Z. Chen, X. Pan, J. Gan, Y. Zheng Food Chem. 231, 365 (2017)

22.- F.J. Lara, D. Chan, M. Dickinson, A.S. Lloyd, S.J. Adams J. Chromatogr. A, 1496, 37 (2017)

23.- A. Parvin Zohrabi, M. Shamsipur, M. Hashemi, B. Hashemi Talanta 160, 340 (2016)

24.- M.H.B. Müller, A. Polder, O.B. Brynildsrud, M. Karimi, E. Lie, W.B. Manyilizu, R.H. Mdegela, F. Mokiti, M.M. Murtadha, H.E. Nonga, J.U. Skaare, J.L. Lyche Environ. Res. 154, 425 (2017)

25.- W. Huang, P. Peng, Z. Yu, J. Fu Appl. Geochem. 18, 955 (2003)

26.- F. Sanchez-Rojas, C. Bosch-Ojeda, J.M. Cano-Pavon Chromatographia 69, 79 (2009)

27.- C.A. Oliveira Ribeiro, Y. Vollaire, A. Sanchez-Chardi, H. Roche Aquatic Toxicol. 74, 53 (2005)

28.- N. Ochiaia, T. Ieda, K. Sasamoto, Y. Takazawa, S. Hashimoto, A. Fushimi, K. Tanabe J. Chromatogr. A 1218, 6851 (2011)

29.- G. Satpathy, Y. Tyagi, R. Gupta Food Chem. 127, 1300 (2011)

30.- M.R. Driss, M.C. Hennion, M.L. Bouguerra J. Chromatog. A 639, 352 (1993)

31.- G. Ehlers, A. Loibner Environ. Poll. 141, 494 (2006)

32.- H.R. Allcock Chem. Rev. 72, 315 (1972)

33.- C.W. Allen Chem. Rev. 91, 119 (1991)

34.- D. E. Çirali, O. Dayan, N. Özdemir, N. Hacıoglu Polyhedron 88, 170 (2015)

35.- D. Kumar, A.J. Elias J. Fluor. Chem. 166, 69 (2014)

36.- A. Uslu, E. Özcan E. J. Mol. Struc. 1142, 116 (2017)

37.- I. Ün, H. İbişoğlu, S.S. Ün, B. Çoşut, A. Kiliç A. Inor. Chim. Acta 399, 219 (2013)

38.- D. Prasanna, V. Selvaraj J. Coll. Int. Sci. 472, 116 (2016)

39.- Y.J. Shin, Y.R. Ham, S.H. Kim, D.H. Lee, S.B. Kim, C.S. Park, Y.M. Yoo, J.G Kim, Kwon, S.H. Shin J. Ind. Eng. Chem. 16, 364 (2010)

40.- N. Ochiai, K. Sasamoto, F. David, P. Sandra J. Chromatogr A, 1455, 45 (2016)

41.- H. Piri-Moghadam, E. Gionfriddo, A. Rodriguez-Lafuente, J.J. Grandy, H.L. Lord, T. Obal, J. Pawliszyn Anal. Chim Acta 964, 74 (2017)

42.- G. Bapat, C. Labade, A. Chaudhari, S. Zinjarde Adv. Coll. Inter. Sci. 237, 1 (2016)

43.- H. Esfandian, A. Samadi-Maybodi., B. Khoshandam, M. Parvini J. Taiwan Inst. Chem. Eng. 75, 164 (2017)

44.- S. Zhang, Q. Yang, X. Yang, W. Wang, Z. Li, L. Zhang, C. Wang, Z. Wang Talanta 166, 46 (2017)

45.- A. Derylo-Marczewska, M. Blachnio, A.W. Marczewski, A. Swiatkowski, B. Buczek Chem. Eng. J. 308, 408 (2017)

46.- P. Vanraes, H. Ghodbane, D. Davister, N. Wardenier, A. Nikiforov, Y.P Verheust, Van S.W.H. Hulle, Q. Hamdaoui, J. Vandamme, J. Van Durme, P. Surmont, F. Lynen, C. Leys Water Res. 116, 1 (2017)

47.- S. Hua, J.L. Gong, G-M Zeng, F-B Yao, M. Guo, X-M Ou Chemosphere 177, 65 (2017)

48.- P.K. Boruah, B. Sharma, N. Hussain, M.R. Das Chemosphere 168, 1058 (2017)

49.- Chen Z., Fu J., Wang M., Wang X., Hang R. J. Zhang, Q. Xu J. Hazard Mater. 273, 263 (2014)

50.- Z. Chen, J. Fu, M. Wang, X. Wang, J. Zhang, Q. Xu Appl. Surf. Sci. 289, $495(2014)$

51.- M. Maeda, K. Kuroyanagi, S. Sakurai, T. Yamanaka , E. Yashima Macromolecules 44 (8), 2457 (2011)

52.- A. Welle, M. Grunze, D. Tur J. Colloid Interf. Sci. 197, 263 (1998)

53.- K. Miyata, Y. Watanabe, T. Itaya, T. Tanigaki, K. Inoue Macromolecules 29, 3694 (1996)

54.- W. Zheng, M. Guo, T. Chow, D. Bennett, N. Rajogopalan J. Hazard. Mater. 181, 121 (2010)

55.- J. Rivas, M.I. Toral., P. Richter J. Chil. Chem. Soc. 57, 1087 (2012)

56.- Y. Qiu, X. Xiao, H. Cheng, Z. Zhou, G.D. Sheng Environ. Sci. Technol. 43, $4973(2009)$

57.- Y. He, J. Xu, H. Wang, Z. Ma, J. Chen Environ. Res. 101, 362 (2006)

58.- G. Limousin, J.P. Gaudet, L. Charlet, S. Szenknect, V. Barthes, M. Krimissa App. Geochem. 22, 249 (2007).

59.- S. Salvestrini, V. Leone P. Iovino, S. Canzano, S. Capasso J. Chem. Thermodyn. 68, $310(2014)$ 